\title{
Cross-Border Cooperation in the Danube-Lined Romanian/Bulgarian Border-Space. Geographical Considerations
}

\author{
Săgeată RaduA*, Dumitrescu BiancaA, Damian Nicoleta ${ }^{A}$ \\ Received: March 2009 | Revised: May 2010 | Accepted: May 2010
}

\begin{abstract}
Since a number of transnational issues have been cropping up, the need was felt for the existence of a unitary system to tackle them. So, the building of some cross-border co-operation structures both at local level [cross-border zones] and at regional level [Euroregions] appeared as highly necessary and desirable. Their typology depends on the intensity and character of cross-border fluxes, the existence of local convergence cores, and of elements of complementariness and homogeneity between the two frontier spaces. The Danube-lined Romanian-Bulgarian frontier represents an axis of discontinuity between two natural regions, each with its own district traits: the Romanian Plain in the north and the Pre-Balkan Mountain in the south. As a result, the limitrophe border zone shows particular social and economic characteristics. Although the Danube River has favoured the emergence of an urban area, yet the respective towns do not form a coherent system, the zone itself being extremely rural as a whole. The Romanian-Bulgarian cross-border zone in the Danubian sector features by a sudden variation in transversal fluxes, concentrating on certain directions imposed by the pattern of communication routes and the layout of doublet towns. Most fluxes pass through the Giurgiu-Ruse sector, a strong argument in favour of establishing a Euro-region based on the cross-border cooperation between the two towns.
\end{abstract}

Key words: Cross-border cooperation, Cross-border zone, Euroregion, Doublet settlements, Danube, Romania, Bulgaria.

\section{Theoretical and methodological considerations}

The contradiction between institutional division of the territory and the existence of cross-border issues that have requested a unitary approach and consequently a cross-border cooperation led to the appearance of new types of regional cooperation structures. Which coincide with the state frontiers: cross-border zones and Euroregions. This kind of cooperation should take into consideration the fact that between the two cross-border zones there is a strip of frontier and, most of the times, there are different legislations that induce different requests regarding the cooperation framework. Consequently, the braking up process represents the main threat to the cross-border regions; if this process is not properly coordinated at the central level, there is the risk of loosing control, the cross- border region gravitating towards one of the coparticipant states.

The issues that fuel the dynamic of the crossborder zones are part of the level of harmonization of the policy for the development of the two crossborder zones that come in contact. The areas situated on each side of the border have, or have not the tendency to evolve in the same way, as a result of central and local policy, but also the local specific situations, which impose the cross-border zone type.

\section{Cross-border zones. \\ Types of cross-border zones}

Largely speaking, the cross-border zone stands for the space situated on each side of the frontier, with breadths varying between 30 and $60 \mathrm{~km}$, characterized by a clear variation of human and mate-

\footnotetext{
A Institute of Geography, Romanian Academy, Bucharest, Romania

* Corresponding author: Radu Săgeată, e-mail: radusageata@yahoo.com
} 
rial fluxes. The decisive elements that define the cross-border space are the structure and configuration of state frontiers that give the cross-border fluxes certain peculiarities according to mass, structure and also the layout of local convergence core, which impose the directions of these fluxes. Consequently, the identity of the cross-border space depends on the elements of complementariness and homogeneity between the two frontier spaces, while the polarization of the cross-border cooperation directions is influenced by the layout of human settlements, especially those with local and regional polarization role.

Depending on population's homogenous or heterogeneous characteristic, national minorities presence or absence, the degree of infrastructure development and, not least, the historical background that in time favoured or limited the crossborder fluxes, cross-border zones have different characteristics. The intensity and variation of local transversal fluxes had as a result the individualization of two theoretical models of cross-border zones (Bădescu, Dungaciu, I995):

I. Cross-border zones characterized by a sudden variation of fluxes due to the homogeneous trait of the populations within the two areas that come in contact and relatively closed borders that overlap naturally inaccessible regions with low inhabiting potential and less developed infrastructure. They coincide with mountainous or desert regions or great rivers that have functioned as barriers for the population exchanges and, depending on them there appeared the world important cultural cutting up. This is the case of the Himalayan mountainous system, which lies between the Buddhist Tibet and the Indian sub-continent, as well as the Sahara that was a barrier in the Arab civilization's spreading towards the southern Africa. In their turn, the Andes, the Pyrenees or the Pamir functioned as separation areas, being ideal domains for mapping out.

2. Cross-border zones within which transversal fluxes vary slowly due to a progressive population mixing, minorities' presence on each side of the border as a result of old interaction rapports established in time under the influence of a favourable natural environment, well-individualized settlement systems and complementary economies. The interior borders of the European Union are a typical example, the identity of cross-border zones being given by the way in which frontiers have transgressed and regressed in history time. From rupture elements for the two political entities with different traits, they become welding, harmonization spaces with specific economic and cultural peculiarities.

\section{Cross-border zones and their role in setting up Euro-regions. Types of Euro-regions}

Analysing the cross-border zones with Romanian participation from this point of view, it can be said that while the southern cross-border zones (Romanian-Bulgarian one and Romanian-Serbian one) have characteristics similar to those in the first category; those with the Republic of Moldavia and Ukraine, due to the spreading of the Romanian ethnic block on each side of the border, join the second category. The Romanian-Hungarian cross-border zone can also be included in the second category; the Romanian authorities see this zone as an opening gate towards the Occident, the European and Euro-Atlantic structures, while Budapest sees it as a linking gate with the Hungarian communities from Transylvania. That is why this cross-border zone was extended by setting up the first Euro-region with Romanian participation: the Carpathian Euro-region, Danube-Mureş-Tisa Euro-region (DKMT) and, recently, Bihor-Hajdú Bihar Euro-region, based on the Oradea-Debrecen collaboration.

Near the eastern Romanian border there were constituted three: The Upper Prut, The SiretPrut-Nistru and The Lower Danube both with participation of two and three states: Romania, the Republic of Moldavia and Ukraine. Their unity is based first of all on ethnic element since they unify territories with compact or majority Romanian population, which were governed by the former Soviet Union following the second Soviet ultimatum at June, the $28^{\text {th }}$, I940, a direct consequence of the secret German-Soviet treaty for non-aggression (Ribbentrop-Molotov). The intense inhabiting on both banks of the river Prut also had an important contribution, the doubletsettlements acting as relays of inter-connection of the two settlement systems, crystallized on a common historical background.

In the ethnic unity is the main bound between the territories on the left and right side of the river Prut that make up the three Euro-regions, Romania's approaches for the integration within the European and Euro-Atlantic cooperation structures request safer frontiers in the East and the control of migratory fluxes on this direction. Thus, the river Prut is on the one hand an integration axis due to the continuity of the ethnic and linguistic element, density and inhabiting continuity on its both banks, and on the other hand as a fragmenting one, because it may become a relatively stable border NATO and European Union, which requires a milieu specific for cross-border cooperation.

So, Euro-regions represent territorial structures created to intensify the inter-regional and cross-border cooperation, so as to obtain a coher- 
ent space for economic, scientific, social and cultural development.

Their cropping up is closely related to the intense cross-border cooperation within the western European space; urban nuclei of cross-border polarization and state border configuration are the main factors that generate them. The rapid in dustrial development in the post war period and the liberalisation of customs regime has contributed to the development of urban agglomerations that have extended, exceeding the national territory. The first Euro-regions were at the Swiss border, based on the polarization areas of Basel (Regio Basilensis), Geneva (Regio Genevensis), Milan (Regio Insubrica) towns, the fluxes complementarities and linguistic unity representing the main factors that have cropped them up.

Another category of Euro-regions, mainly set up after I990, stands for macro-territorial structures that are result of the aggregation of the first rank administrative-territorial units, generally structured along the important pan-European traffic corridors. The North Euro-region, based on the cooperation among Kent English County and Trans-Pyrenees Mediterranean Euro-region that includes Catalonia, Languedoc-Rousillon and Midi Pyrenees regions or the Saar-Lor-Lux (Saar-Lorena-Luxembourg) Euro-region are typical examples of this kind of Euro-regions.

\section{Doublet settlements and their role in structuring the cross-border cooperation directions}

The separation caused by the hydrographical systems led to the individualization of some nuclei of transversal fluxes concentration, as a result of the favourable local topographic conditions.

Thus, the presence of crossing fords has led to population concentration on both banks and gradually doublet settlements appeared, with local or even regional polarization role. Such examples are numerous, still typical are those on Rio Grande, at the Texan-Mexican border (El Paso-Ciudad Juárez, Presidio-Ojinaga, Eagle Pass-Piedras-Negras, Laredo-Nuevo Laredo, Rio Grande City-Ciudad Camargo, Brownsville-Matamoros), on the Congo river (Bangui-Zongo and Brazzaville-Kinshasa), or those on the Oder-Neisse line, at the German-Polish border (Ahlbeck-Swinujscie, Pomellen-Szczecin, Schwedt-Angermünde-Chojna, Küstrin-Kietz-Kostrzyn, Frankfurt am Oder-Slubice, Guben-Gubin, Cottbus-Forst-Olszyna, Bad Muskau-Leknica, Görlitz-Zgorzelec and Zittau-Sieniawka) (Wackermann et al., I99I) or the settlement doublets lining the lower course of the Prut River on the frontier between Romania and the Republic of Moldova, some of these settlements actually bear the same name, e.g. Sculeni-Sculeni, Medeleni-Mede- leni, Grozeşti-Grozeşti, Răducani-Tochil Răducan, Pogoneşti-Pogoneşti, etc.).

In time, the nuclei of cross-border demographic concentration act as embryos of Euro-regions' birth through the extension of the low border traffic at a macro-territorial scale based on the existing relationships within the settlements systems from the coterminous administrative-territorial units (Figure I).

This is also the case of the cross-border zone from the Romanian-Danube sector; throughout the centuries, the river was both an important axis of transversal fluxes structuring and the main navigation thoroughfare, which favoured the longitudinal fluxes between Central Europe and the Black Sea Basin. Its presence generated a real "urban belt" in the southern part of this country, contributing to the appearance of a specific economic activity, thus increasing the polarisation potential of harbour towns. The latter is closely related to the process of connecting harbours to the land transport system, as well as the role of some towns that are customs points (Tălângă, Braghină, 200o). The doublet settlements with a leading role in setting up the connection among Central Europe, the Balkan Peninsula and Asia Minor have the function of guiding the cross-border fluxes in the Danubelined sector of the Romanian-Bulgarian border.

\section{Cross-border fluxes along the Romanian-Bulgarian sector of Danube. Evolutions and characteristics}

The Danube-lined Romanian-Bulgarian border represents an axis of discontinuity between two natural regions, each with its own distinct traits: in the north - the Romanian Plain that comes in touch with the Danube River in a sector of flood plains and well-developed terraces, and in the south - the Lugodorie Plateau, a part of eastern Danube plain, Bulgaria, with altitudes between 200 and $400 \mathrm{~m}$, gradually descending northwards reaching Ioo m nearby the Ruse town. Thus, since historical times a well-individualized natural border was established, due to the numerous tributaries that flow into the Danube River within the hydrographical convergence area near Belgrade (Drava, Tisa, Sava, Morava), which virtually doubles its flow; this border has always been difficult to cross, having defensive function, too, except for some fords that are the result of the favourable relief and that gradually became transversal circulation axes. These have favoured the individualization of some nuclei of human concentration, leading to the appearance of doublet settlements with local or regional polarization function: $\mathrm{Ca}-$ lafat - Vidin, Rast - Lhom, Bechet - Oreahovo, Turnu Măgurele - Nikopol, Zimnicea - Sviştov, 


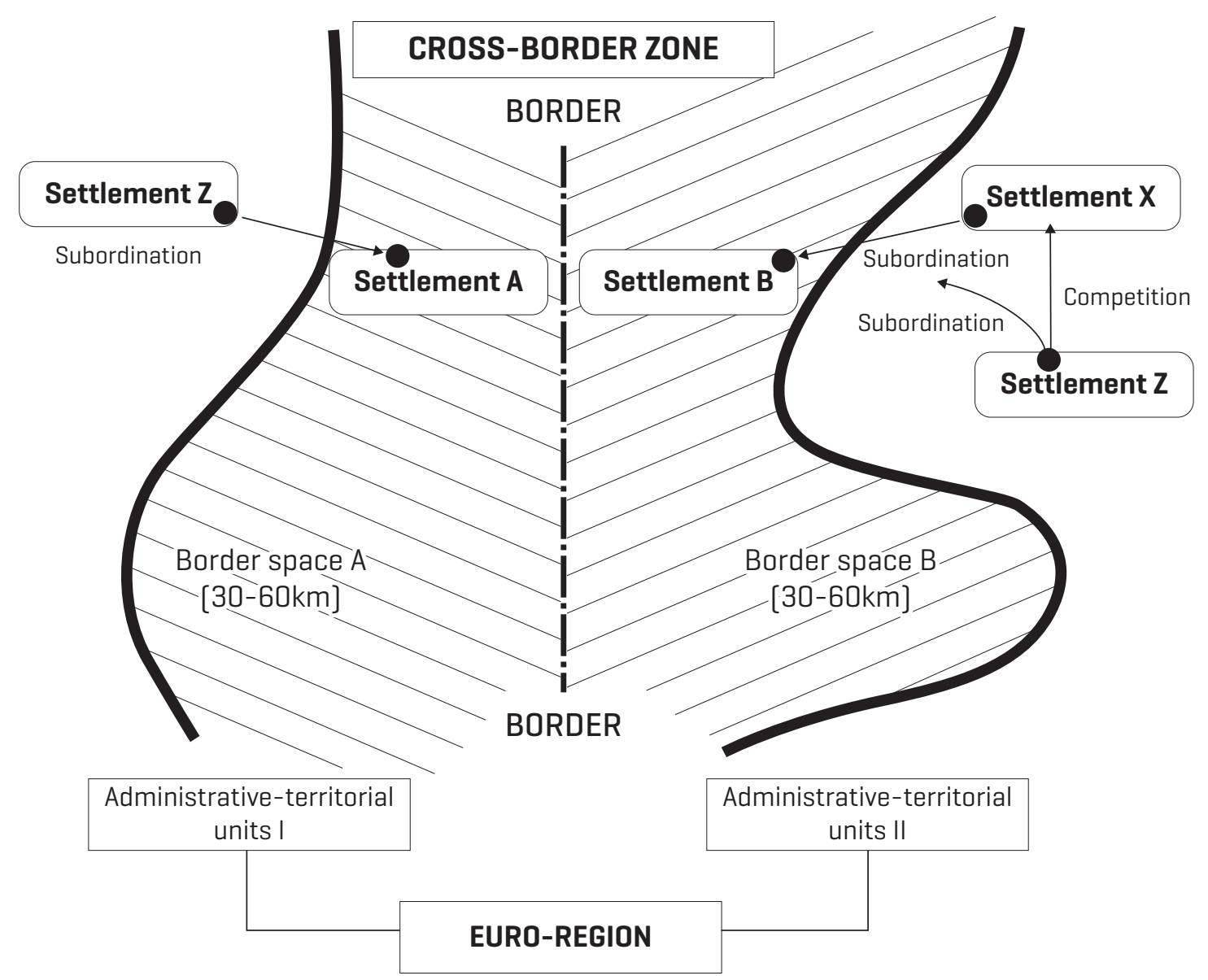

Figure 1 The role of the human settlements in the Euro-region structure

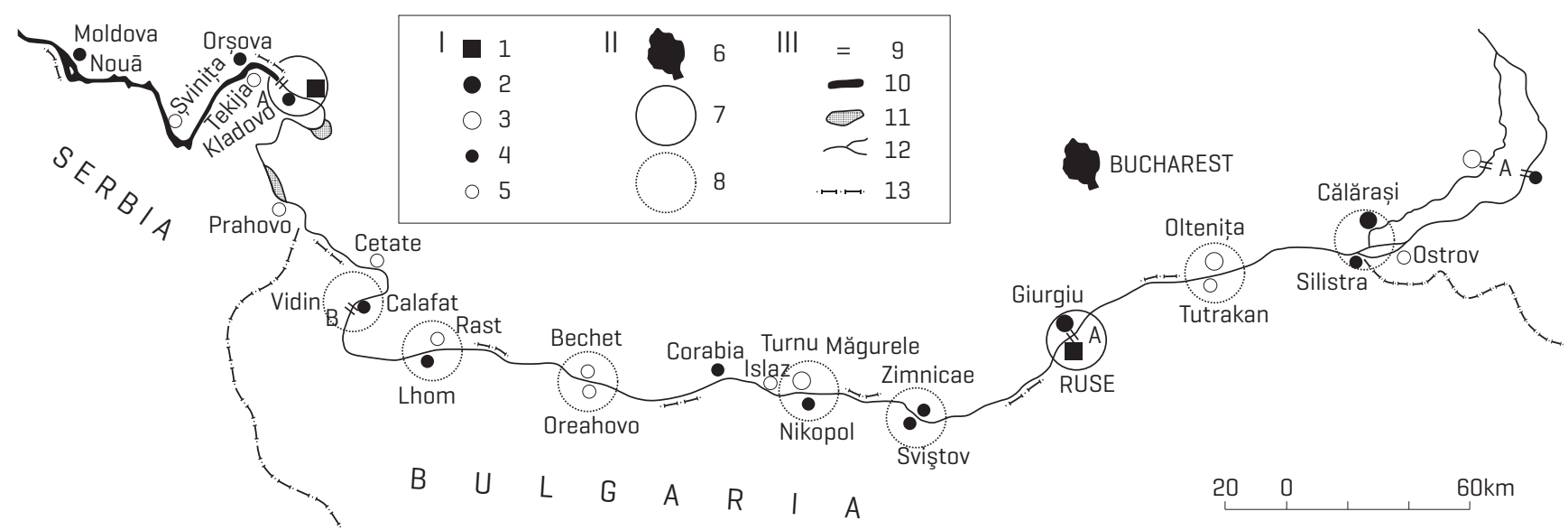

Figure 2 The doublet settlements within the Danube-lined sector of the Romanian border and categories of connections materialized through them

I. Settlements: 1. 100,000-500,000 inh., 2. 50,000-100,000 inh., 3. 25,000-50,000 inh., 4. 10,000-25,000 inh., 5. 0-10,000 inh.

II. Type of realized connection: 6, Capital, 7, International traffic, 8, Low border traffic; III, Others: 9, Bridge [A - existent, B - by project],

10. Lake, 11. Island, 12. The Danube, 13. Border. 
Giurgiu - Ruse, Olteniţa - Tutrakan and Călărași - Silistra (Figure 2).

The relatively closed characteristic of the frontier, due to specific natural, historical and social characteristic features, has been reflected also in the dynamics of cross-border exchanges. The Danube sector of the Romanian-Bulgarian cross-border area is characterized by a relatively sudden variation of transversal fluxes, as a result of the homogeneousness of the populations within the two boundary areas that come in touch with one another, in the conditions of an uneven dwelling system and a poor communication infrastructure. It is also worth mentioning the historic stability; in its lower sector, the Danube River acted as a segregation axis since Antiquity. "The Danube line" was marked by the following Roman settlements: Ratiaria (downstream of Vidin), Oescus (Ghighen, where the Iskar river flows into Danube), Novae (Sviştov), Durostorum (Silistra), Axiopolis (Cernavodă) and Carsium (Hârşova). There was also a "line" of the Dacian Danube, older than that of the Roman Danube: Călăraşi (near the river Jiu), Sucidava-Oescus and Zimnicea - Novae (bridge extremities) (Popp, 1988).

During the 485 years of Ottoman domination, the main directions of the cross-border vectors were given by the doublet settlements by the doublet settlements Giurgiu-Ruse (Rusciuc) and Turnu-Nikopole, because they become rayahs in order to better control the commerce and navigation on the Danube River and also as a result of the construction of the Giurgiu-Bucharest railway in 1867 , the second oldest railway in Romania, having a great strategic importance, connecting the capital with the biggest Romanian port at that time. The social-economic and cultural European influence was felt in the Danube harbours beginning with the $19^{\text {th }}$ century.

After the Second World War, the Danube River became an axis which attracted different industries: chemistry at Vidin, Drobeta-Turnu Severin, Turnu Măgurele, Sviştov and Giurgiu; thermo-electrical power stations at Galaţi and Ruse; integrated metallurgic complexes at Galaţi and Călăraşi; nuclear power stations at Kozlodui and Cernavodă. The consequence - ecological problems with crossborder implications, favoured by northeast and northwest winds; this has tensioned the Romanian-Bulgarian relationships various times. The commercial fluxes were almost exclusively concentrated on the Giurgiu-Ruse direction, on the one hand because of the importance of the two towns within the national urban systems, and on the other hand because they were connected by the only bridge that crosses the Danube River in the Romanian-Bulgarian frontier sector.

In 1992, the Danube-Main-Rhine canal connected the Danube River with North-Western Eu- rope and with the Northern Sea. The advantage could not be capitalized, first because of the embargo imposed Yugoslavia, then because of the damages caused by the American bombardments on Serbia, which blocked the navigation in the Novi-Sad area, causing immense prejudices to the economies of the two countries downstream. The removal of these destructions and the navigation reopening offer new perspectives for the revitalization of the Danube axis in general and the cross-border collaboration between Romania and Bulgaria in particular.

The Cross-border Cooperation Programme "Romania-Bulgaria 2007-2013" is aimed at coordinating the cooperation development actions of several actors (economic, political, institutional, local authorities, etc.) in order to make the best use of the opportunities offered by the joint development of the cross-border region.

\section{The delimitation of the Romanian border space within the Danube sector}

The topographic peculiarities, preferential directionalization and the intensity of the cross-border fluxes are the factors that establish the individualization and characteristics of a cross-border area. The delimitation of the Romanian sector of the cross-border area depends on two essential elements: on the one hand the closed character of the border, which imposes its narrowness, and on the other hand the preferential orientation of the transversal circulation axes, which causes the width in some specific sectors of maximum intensity of the cross-border fluxes. These are given by the exchange vectors caused by the doublet settlements, location and type of the customs points (low frontier traffic, international traffic etc) and not least by the specific of the bound axis (bridge or ferry-boat), which determines the intensity of cross-border fluxes. The newly constituted Euro-regions within the Romanian Danube sector - The Danube $2 I^{\text {st }}$ and Giurgiu-Ruse are also of a great importance (Table I). The nuclei of the polarization of transversal fluxes are represented by the pair-towns Calafat - Vidin, Bregovo - Negotin, Kula - Zaječar and Giurgiu - Ruse and also by the two bridges that cross the Danube from the Romanian-Bulgarian border sector, one already exists, the other one is to be built.

Consequently, we have highlighted the Romanian border space adjacent to the Romanian-Bulgarian frontier in the Danube sector, which is made up of all the territorial-administrative units coterminous to the Danube, with extensions inside the country in the vicinity of the main alignments of cross-border fluxes concentration: Calafat - Vidin and Giurgiu - Ruse: 
Table 1 Euro-regions at the Romanian/Bulgarian border space [2009]

\begin{tabular}{|c|c|c|c|}
\hline $\begin{array}{l}\text { Euro-region, Set-up } \\
\text { year, Surface }\end{array}$ & Countries & Administrative - territorial units & Polarising cores \\
\hline \multirow{2}{*}{$\begin{array}{l}\text { GIURGIU-RUSE, } 2001 \text {, } \\
2,784 \mathrm{~km}^{2}\end{array}$} & Romania & $\begin{array}{l}1 \text { town [Giurgiu] and } 14 \text { communes [Băneasa, Daia, Frăteşti, } \\
\text { Găujani, Gogoşari, Gostinu, Izvoarele, Mihai Bravu, Oinacu, } \\
\text { Prundu, Putineiu, Slobozia, Stăneşti and Vedea] }\end{array}$ & Giurgiu \\
\hline & Bulgaria & $\begin{array}{l}7 \text { municipalities [Borovo, Dve Mogli, Pârgovo, Ruse, Slivo- } \\
\text { Pole, Țar Kaloian and Vetovo] }\end{array}$ & Ruse \\
\hline \multirow{3}{*}{$\begin{array}{l}\text { DANUBE 21, } \\
2002,9,500 \mathrm{~km}^{2}\end{array}$} & Romania & $\begin{array}{l}1 \text { town [Calafat] and } 4 \text { communes [Cetate, Ciupercenii Noi, } \\
\text { Desa and Poiana Mare] }\end{array}$ & Calafat \\
\hline & Bulgaria & $\begin{array}{l}8 \text { municipalities [Belogradcic, Dimovo, Kula, Lom, Mokres, } \\
\text { Novo Selo, Rujiniti and Vidin] }\end{array}$ & Vidin \\
\hline & Serbia & $\begin{array}{l}8 \text { municipalities [Bolivat, Bor, Kladovo, Kniajevat, Majdanpek, } \\
\text { Negotin, Sokobanja and Zaječar] }\end{array}$ & Zaječar \\
\hline \multirow{2}{*}{$\begin{array}{l}\text { DANUBIUS, } \\
2002,6,310 \mathrm{~km}^{2}\end{array}$} & Romania & 1 county [Giurgiu] & Giurgiu \\
\hline & Bulgaria & $\begin{array}{l}8 \text { municipalities [Borovo, Byala, Dve Mogli, Ivanovo, Ruse, } \\
\text { Slivo Pole, Tsenovo and Vetovo] }\end{array}$ & Ruse \\
\hline \multirow{2}{*}{$\begin{array}{l}\text { SOUTH DANUBE, } \\
2002,1,646 \mathrm{~km}^{2}\end{array}$} & Romania & $\begin{array}{l}4 \text { towns [Alexandria, Roşiori de Vede, Turnu Măgurele and } \\
\text { Zimnicea] }\end{array}$ & $\begin{array}{l}\text { Alexandria, Roşiori de Vede, } \\
\text { Turnu Măgurele, Zimnicea }\end{array}$ \\
\hline & Bulgaria & 3 municipalities [Belene, Sviştov and Nikopol] & Belene, Sviştov, Nikopol \\
\hline \multirow{2}{*}{$\begin{array}{l}\text { DANUBE - DOBROGEA, } \\
2002,24,177 \mathrm{~km}^{2}\end{array}$} & Romania & 3 counties [Călăraşi, Constanța, Ialomița] & $\begin{array}{l}\text { Constanța, Călăraşi, } \\
\text { Slobozia, Mangalia }\end{array}$ \\
\hline & Bulgaria & 2 districts [Dobrich, Varna] & Varna, Dobrich, Silistra \\
\hline
\end{tabular}

- Mehedinţi county: Pristol, Gârla Mare and Salcia;

- Dolj county: Cetate, Maglavit, Calafat, Ciupercenii Noi, Desa, Poiana Mare, Piscu Vechi, Rast, Negoi, Bistreţ, Măceşu de Jos, Gighera, Ostroveni, Bechet, Călăraşi and Dăbuleni;

- Teleorman county: Islaz, Turnu Măgurele, Ciuperceni, Traian, Seaca, Suhaia, Zimnicea, Năsturelu and Pietroşani;

- Giurgiu county: Găujani, Vedea, Slobozia, Săneşti, Giurgiu, Frăteşti, Daia, Oinacu, Gostinu and Prundu;

- Călăraşi county: Chirnogi, Olteniţa, Spanţov, Chiselet, Dorobanţu, Ciocăneşti, Grădiştea, Cuza Vodă and Călăraşi.

These administrative-territorial units are part of the area in which the Cross-border Cooperation Programme "Romania-Bulgaria 2007-2013" has become effective. There are seven Romanian counties bordering on the Bulgarian frontierline (Mehedinţi, Dolj, Olt, Teleorman, Giurgiu, Călăraşi and Constanţa) and eight Bulgarian districts close to the frontier with Romania (Vidin, Vratsa, Montana, Pleven, Veliko Tyrnovo, Ruse, Silistra and Dobrich).

\section{Case Study: The Delimitation of the Giurgiu - Ruse Euroregion}

If in its upper and central course, the Danube River flows through countries, towns and some capitals, being a unifying element, in some cases even having a symbol value (Vienna, Bratislava, Budapest, Novi Sad, Belgrade), its lower sector acted as a natural frontier long time ago when two countries - Romania and Bulgaria appeared. It is a wellindividualized natural border, due to the numerous tributaries that flow into the Danube in the hydrographical convergence area near Belgrade (Drava, Tisa, Sava, Morava), which practically double its flow; in the course of history, this border was intended to be a difficult border to cross, since it had defensive functions. Thus, in spite of the natural population exchanges, a cross-border zone of relatively sudden variation of transversal fluxes appeared; perhaps it is the most characteristic zone of this type at the Romanian borders. There were some exceptions - some fords, which were the result of the favourable relief and which in time became transversal circulation corridors. Among these, Giurgiu-Ruse became in the course of time the most important connection point in the Danube sector of the Romanian-Bulgarian border. The importance of this bipolar urban nucleus and its distinct position regarding the Romanian-Bulgarian cross-border axes derive from the two towns' size and importance for the national urban systems on the one hand and from their connection by the only bridge existing so far in the Romanian-Bulgarian border sector. That is why before 1989 , commercial fluxes between the Balkan countries and the rest of the continent passed almost exclusively through the GiurgiuRuse sector (Batvarov, I998). 
The position potential is the result of the positioning of the two towns on the connection axis between Bucharest and the Balkan Peninsula, part of the traffic corridor that connects the European countries with Asia Minor and Near Orient, which gives it, from the Romanian point of view, a strategic importance for the Romanian-Bulgarian cross-border collaboration. There is also worth mentioning the Nabucco and AGRI Projects, conceived by the European Union and supported by the U.S., having as main objective the exploitation and transport of the huge hydrocarbon deposits from the Caspic Sea, Central Asia and Caucasus area in which Russia used to have, until very recently, a quasi-monopole and none of these states, except for Georgia, had direct way towards the
Occident. The established routes tend to avoid the Russian Federation and Belarus Republic, passing through Turkey, Bulgaria and Romania, with ramifications towards West (Hungary - Italy) and North (through Poland and the Baltic countries). Taking into account the international and regional geo-political context, the local authorities in the two towns initiated the cropping up of the Giurgiu-Ruse euro-region (Figure 3).

Its delimitation was made considering the urban polarization area, unifying the administrative-territorial communes units that gravitate towards the two towns, based on the distances on land thoroughfare. In the whole, there were elected 20 communes, 14 from Romania and 6 from Bulgaria; the discrepancy is the result of the dif-

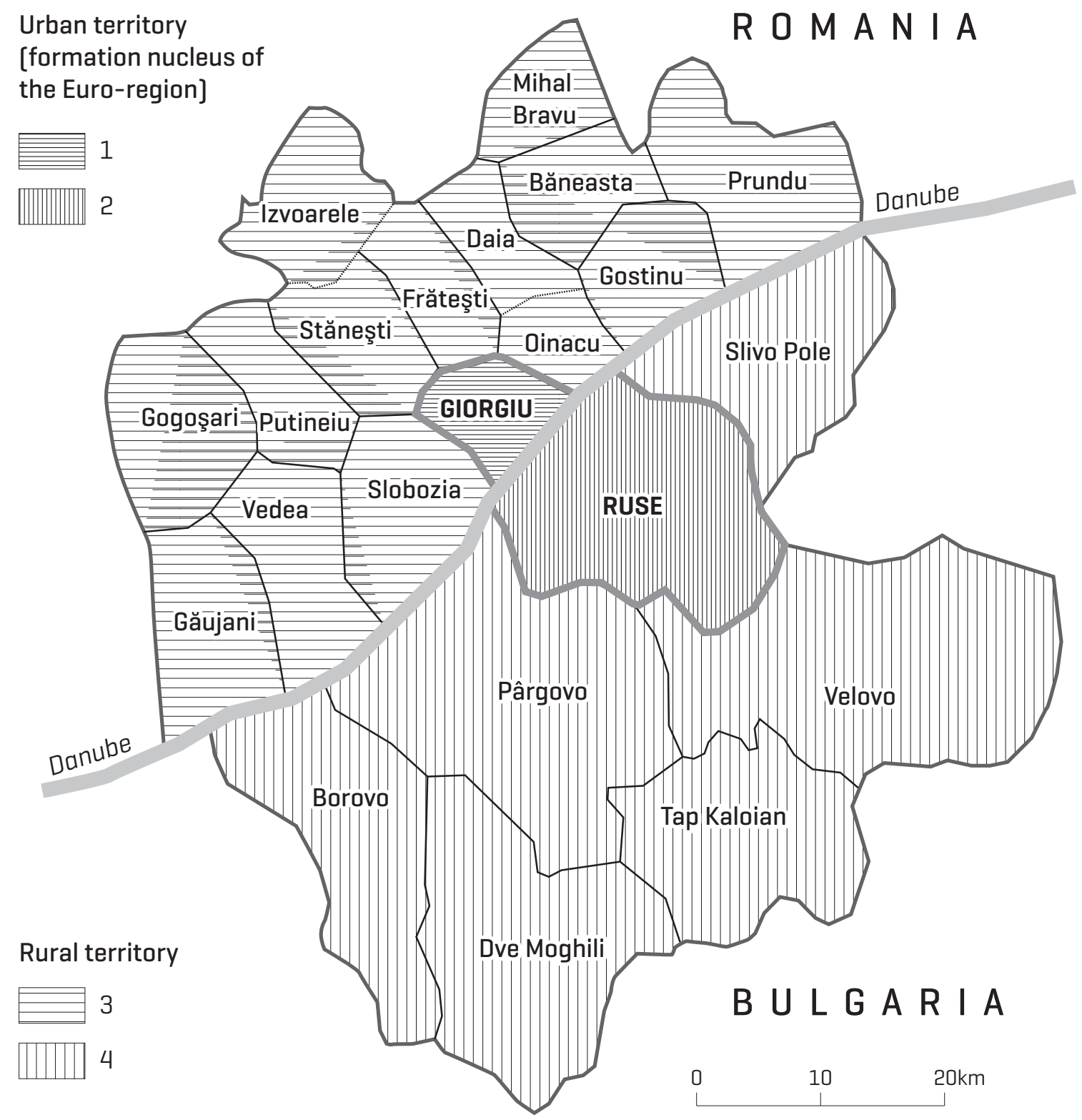

Figure 3 Giurgiu - Ruse Euroregion.

1. Urban administrative territory in Romania [Giurgiu], 2. Urban administrative territory in Bulgaria [Ruse], 3. Rural administrative territory in Romania, 4. Rural administrative territory in Bulgaria. 
Table 2 The administrative-territorial units that make up the Giurgiu-Ruse Euro-region and the distances $[\mathrm{km}]$ to the polarising cores

\begin{tabular}{|l|l|}
\hline Cores & Administrative-territorial units [km] \\
\hline Giurgiu [km] & $\begin{array}{l}\text { Prundu [36], Gostinu [21], Băneasa [19], Mihai Bravu [35], Daia [12], Oinacu [11], Frăteşti [9], Izvoarele [23], } \\
\text { Stăneşti [12], Slobozia [6], Putineiu [20], Vedea [20], Gogoşari [24], Găujani [28]. }\end{array}$ \\
\hline Ruse [km] & Slivo-Pole [19], Vetovo [35], Pârgovo [10], Țar Kalojan [36], Dve Mogli [31], Borovo [45]. \\
\hline
\end{tabular}

ferent structures of local administrative units in the two countries: if the average surface of a Romanian commune is $80.27 \mathrm{~km}^{2}$, that of Bulgarian ones (obstina) is approximately 6 ties larger, on the average $466 \mathrm{~km}^{2}$ (Săgeată, 2002) (Table 2).

The advantages of this delimitation are given by the functionality of the resulting territorial structure, the I4 Romanian and 6 Bulgarian settlements laying at relatively short distances to the two urban cores; in time, they may form functional metropolitan zones, such as Bucharest and Oradea metropolitan zones. Moreover, being situated in the vicinity of Bucharest, but in a profound rural area characterized by a high poverty rate, few possibilities of professional reconversion and poorly developed infrastructure, they may attract some investments, contributing to the area's revitalization, transforming it into a hinterland of the capital city, spreading as far as the Danube. The limited financial resources of the local involved communities represent the disadvantages since we are not considering administrative units at county scale. Still, they can be rectified by implementing a viable local autonomy functioning at the commune level, the success of the Euro-regions within the central continent, delimitated according to the same principles, being unchallenged.

As a general conclusion, it can be said that cross-border spaces are extremely sensible and vulnerable domains at the geographical chances, their identity being the result of the association of some specific ethnical, cultural, geographical, historical, economic, demographical and political factors. The intensification of cross-border fluxes as a result of urbanization and industrialization, unifies areas that were politically and economically divided in the past; Euro-regions are becoming ever more territorial structures with their own traits, generated by cross-border fluxes, which in their turn generate globalizing fluxes (Săgeată, 2004).

\section{References}

Batvarov, M. 1998. Les fonctions changeantes des frontières bulgares. Revue Géographique de l'Est XXXVIII, 4, I5I-I57.

Bădescu, I., Dungaciu, D., I995. Sociology and geopolitic of border I-Il, Ed. Floarea Albastră, Bucureşti, 354-357 (in Romanian)
Becart, A., Brodaty, S. I998. La coopération transfrontalière et le dévelopement local. Hommes et Terres du Nord I, 35-43.

Deică, P. I997. Regiuni transfrontaliere sau euroregiuni? Cross-border regions or Euroregions. Comunicări de Geografie, Ill, Ed. Universităţii din Bucureşti, 365-368.

Dobraca, L. I997. Cross-border relations in the Giurgiu-Ruse Danube sector. Geographical remarks. Revue Roumaine de Géographie 4I, 57-67.

Engel, C., Rogers, J.H. I996. How Wide is the border? American Economic Review 86, 5, III2-II25.

Fourcher, M. (coord.) I999. Géopolitique du Danube. Ed. Ellipses, Paris, 95 pp.

Gaunard, Marie-France I998. La recomposition territoriale des zones frontalières en Pologne par la mise en place d'Eurorégions. Bulletin de l'Association de Géographie Français 76, 4, 429442.

Gonin, P. 1994. Régions frontalières et dévelopement endogène: de nouveaux territoires en construction au sein de l'Union Européenne. Hommes et Terres du Nord 2-3, 6I-70.

Guran, L., Nancu, D., Săgeată, R., Dobre, S. 2002. Socio-economic potential of the RomanianBulgarian border space. Topical geographical consideration. Forum Geografic. Studii şi Cercetări de Geografie şi Protecţie a Mediului, I, I, Ed. Universitaria, Craiova, I22-I32.

Iacob, Gh. I959. Giurgiu. Physical and Economic geographical Considerations. Probleme de Geografie, VI, Ed. Academiei Române, 239-25I. (in Romanian)

Ilieş, Al. 2003. Romania between Millenniums. Borders. Border areas and Border cooperation. Ed. Universităţii din Oradea, Oradea, 236 pp. (in Romanian)

Ilieş, Al. 2004. Romania. Euroregions. Ed. Universității din Oradea, Oradea, 2I8 pp. (in Romanian)

Menville, J. I996. Frontières et capitale - risque régional. Sciences de la Société 37, 97-I09. (in Romanian)

Mihghi, J.V. I963. Boundary studies in political geography. Annals of the Association of American Geographers 53, 407-428.

Nedea, M. 2005. A Model of European integration. Euroregion System from Germany's eastern border. GeoPolitica, III, I3, Ed. Top Form, Bucureşti, 75-82. (in Romanian) 
Neguţ, S. I998. Les eurorégions. Revue Roumaine de Géographie, 42, Ed. Academiei Române, 7585. (in Romanian)

Popp, N. I988. Danube Basin. Nature, man, economy. Ed. Litera, Bucureşti, 205 pp. (in Romanian)

Popa, N. 200I. Racines des évolutions transfrontalières en Europe centrale. Geographica Timisensis X, 55-65. (in Romanian)

Popa, N. 2006. Borders, Border regions and Regional development in Middle Europe. Ed. Universitatii de Vest, Timişoara, 286 pp. (in Romanian)

Popescu, G. 2000. Cross-border Zones. Terra XXX (L), I, 9I-92. (in Romanian)

Popescu, G. 2003. Euro-regional economy. Giurgiu-Ruse Euroregion from poverty to economic development. Studies and Reseach. Ed. ASE, Bucureşti, I34 pp. (in Romanian)

Reynolds, D.R., McNutty, M. I968. On the analysis of political boundaries as bariers: a perceptual approach. East Lakes Geographer 4, 2I-28.

Rougier, H. I999. De la notion de région à celle d'éurorégion. Bulletin de l'Association de Géographes Français 76, 4, 394-396.

Savey, S. 1994. Régions frontalières, régions transfrontalières et/ou pionnieres. Bulletin de la Société Languedocienne de Géographie 28, I-2, 227235.

Săgeată, R. 2002. Cross-border cooperation structures. Giurgiu-Ruse Euroregion. Forum Geografic. Studii şi Cercetări de Geografie şi Protecţie a Mediului, Ed. Universitaria, Craiova, I40-I49.

Săgeată, R. 2004. The Role of the Doublet Settlements in the Euro-regions Structure. A Case Study: The Romanian-Bulgarian border Space in the Danube Sector. "Poland and Romania Enlargement of European Union and NATO”, IGU Political Geography Commission, Carta Blanca, Warsaw, I25-I3I.

Săgeată, R. 2004. Models of Political-administrative regionalisation. Ed. Top Form, Bucureşti, I6o pp. (in Romanian)

Săgeată, R. 2004-2005. Systems of human settlements and cross-border cooperation in the Prut Basin. Studii şi Cercetări de Geografie, LI-LII, Ed. Academiei Române, Bucureşti, 65-78. (in Romanian)
Săgeată, R. 2006. Human Settlements. PoliticalAdministrative Function and Organisation of the Geographical Space. Ed. Universităţii Naţionale de Apărare „Carol I”, Ed. Top Form, Bucureşti, 393 pp. (in Romanian)

Săgeată, R. 2009. Cultural globalisation and Global culture. Regional and Local in Cultural Geography. Ed. Universitară, Bucureşti, 256 pp. (in Romanian)

Săgeată, R. (coord.), Guran L., Dumitrescu B., Damian N., Baroiu Dr. 2004. Solutions to optimize the territorial-administrative organisation of Romania in the perspective of the EU accesion. Ed. Ars Docendi, Bucureşti, I28 pp. (in Romanian)

Seguy, R. I998. L'Eurorégion, un espace economique en construction? Hommes et Terres $d u$ Nord 3, I7I-I74. (in Romanian)

Simileanu, V., Săgeată, R. 2009. Geopolitic of Romania. Ed. Top Form, Bucureşti, 466 pp. (in Romanian)

Tălângă, C., Braghină, C. 200o. Considerations on the Functional evolution of the Danube Port towns. Terra XXX (L), 2, 87-89. (in Romanian)

Vernier, A. I993. Problèmes posés aux régions frontalières. Revue de l'Institut de Recherches Economiques et Sociales 2, 65-92. (in Romanian)

Waack, C. 1996. Russe und Giurgiu - Nachbarstaedte an der Donau. Europa Regional 3, I-I2.

Wackermann, G. I990. Les échanges interculturelles dans les espaces transfrontaliers. Bulletin de l'Association de Géographes Français 67, 5 , 347-356.

Wackermann, G. I99I. Sociétés et aménagements face aux disparités transfrontalières. Revue Géographique de l'Est XXXI, 2, 89-98.

*** 2000, 2005. The Lisbon Strategy. European Union, www.wikipedia.org/wiki/ Lisbon_ Strategy, www.mae.ro

*** 2006. Community Strategic Guidelines on Cohesion 2007-2013 (Council Decision No 2006/702/EC), http://ec.europa.eu/regional_policy/sources/docoffic/2007/OSC/index_ ro.htm

**** 2008. Romania-Bulgaria Cross-Border Cooperation Programme 2007-2013, European Union, Government of Romania \& Government of Bulgaria, www.mdlpl.ro, www.cbcromaniabulgaria.eu 